MEDIALOG: Jurnal IImu Komunikasi, Volume III, No. II, Agustus 2020, hlm 52-64

\title{
ANALISIS ILUSTRASI SOSOK JOKOWI DALAM PENANGANAN PANDEMI COVID-19 PADA SAMPUL MAJALAH TEMPO
}

\author{
Woro Harkandi Kencana ${ }^{1}$ \\ Fakultas Ilmu Komunikasi Universitas Persada Indonesia YAI, Jakarta \\ Email: woro.harkandi@gmail.com
}

\begin{abstract}
ABSTRAK
Majalah menjadi salah satu media penyebaran informasi di Indonesia yang menjangkau target pembaca yang segmented. Sampul majalah merupakan pintu masuk sebuah media cetak, setiap redaksional media mempunyai ciri khas dan karakternya sendiri dalam menentukan gaya sampul majalahnya secara konsep maupun teknik. Pada masa pandemi Covid-19 majalah Tempo menjadikan sosok Jokowi sebagi sampul majalah mereka. Ilustrasi dan teks yang digunakan merupakan bentuk kritikan terhadap kebijakan dalam penanganan Covid-19.Penelitian ini ingin mengkaji makna pada sampul majalah Tempo dalam edisi yang menampilan sosok Presiden Joko Widodo dalam menangani tahapan krisis pandemi Covid-19 di Indonesia. Metode yang digunakan dengan pendekatan kulitatif dan analisis semiotika Pierce. Analisis dilakukan pada empat edisi majalah Tempo yang menampilkan sosok Jokowi pada edisi 915 Maret 2020, 16-22 Maret 2020, 6-17 April 2020 dan 1-7 Juni 2020. Hasil penelitian ini pemaknaan pada sampul majalah Tempo di masa ini terbagi menjadi tiga tahap dalam menampilkan sosok presiden Joko Widodo.Masa awal krisis,maintance dan resolusi. Pada tiap tahapannya, sosok Jokowi dalam bentuk ilustrasi ditampilkan secara satire, metafora dan personifikasi. Pada masa Pandemi Covid-19 sosok Jokowi ditampilkan sebagai bentuk kritik media terhadap segala kebijakan yang dikeluarkan pada masa pemerintahan presiden Jokowi.
\end{abstract}

Kata Kunci: sampul majalah;pandemi Covid-19,semiotika

\section{ANALYSIS OF JOKOWI FIGURE ILLUSTRATION IN HANDLING OF COVID-19 PANDEMICS IN TEMPO'S MAGAZINE COVER}

\begin{abstract}
Magazine is one of the media for the dissemination of information in Indonesia that reaches the targeted audience segmented. The cover of a magazine is the entrance of a print media, each media editor has its own characteristics and character in determining the style of the magazine cover in concept and technique. During the Covid-19 pandemic, Tempo magazine made Jokowi's figure the cover of their magazine. The illustrations and texts used are a form of criticism of the policy in handling Covid-19. This research wants to examine the meaning on the cover of Tempo magazine in an edition that features the figure of President Joko Widodo in handling the stages of the Covid19 pandemic crisis in Indonesia. The method used is Pierce's semiotic analysis and qualitative approach. The analysis was conducted on four editions of Tempo magazine which featured the figure of Jokowi on the 9-15 March 2020 edition, 16-22 March 2020, 6-17 April 2020 and 1-7 June 2020. The results of this study were the meanings on the cover of Tempo magazine at this time were divided into three stages in presenting the figure of president Joko Widodo.The beginning of the crisis, maintance and resolution. At each stage, Jokowi's figure in the form of illustrations is displayed in satire, metaphor and personification. During the Covid-19 Pandemic, Jokowi's figure was presented as a form of media criticism of all policies issued during the administration of President Jokowi.
\end{abstract}

Keywords: cover magazine;covid-19 pandemics, semiotic 
Korespondensi: Woro Harkandi Kencana,S.Sos,M.Ikom. Universitas Persada Indonesia YAI. Jakarta. 13720. No. HP, WhatsApp: 081905664490 Email: woro.harkandi@gmail.com

\section{PENDAHULUAN}

Peningkatan kasus pasien positif Covid-19 di Indonesia sejalan dengan pemberitaan yang terus bermunculan di media. Masyarakat membutuhkan informasi mengenai wabah yang telah menjadi pandemi secara global. Isu ini menjadi news value yang tinggi dalam pemberitaan media di segala aspek.

Pandemi Covid-19 tidak hanya menciptakan krisis kesehatan, tetapi juga memunculkan krisis ekonomi, sosial-kemanusiaan, pendidikan hingga politik dalam menentukan kebijakan pada setiap negara secara global. Krisis ini menjadi sumber informasi media yang dibutuhkan oleh masyarakat. Agenda media yang bermunculan berupa isu dasar covid 19 terkait dengan info medis dan protokol kesehatan termasuk jaga jarak (social distancing/physical distancing), kebijakan publik pemerintah dalam pencegahan dan penanganan Covid-19. Sehingga memunculkan kritik terhadap penangan pemerintah dan komunikasi publik pada krisis ini. Hingga berita simpang siur/ hoax yang bermunculan di sosial media.

Representasi pemberitaan krisis di media selama masa pandemi Covid 19 menurut Utomo (2020:315-316) berdasarkan elemen-elemen pemikiran Barbara Reynolds dan Matthew W. Seeger (2005) yang merumuskan Crisis and Emergency Risk Communication (CERC). Posisi jurnalisme selama masa krisis terbagi menjadi tiga
.Pertama, di awal-awal krisis, beberapa media di Indonesia terjebak untuk mengarusutamakan konspirasi yang sulit dipertanggungjawabkan kebenarannya. Kedua, afiliasi politik dan kepemilikan media memiliki pengaruh yang penting terhadap pemberitaan. Konsekuensinya, media tidak bisa berjarak apabila beririsan dengan kepentingan politik pemiliknya. Ini berimplikasi pada berita-berita yang tidak bisa menjaga sikap kritis dan independensi dari kekuasaan. Ketiga, sikap keras media yang advokatif terhadap pemerintah. Dalam negara demokratis, kondisi ini adalah hal yang wajar. Pemerintah butuh media yang mengawasi kekuasaan agar tetap akuntabel dan transparan.

Majalah menjadi salah satu media penyebaran informasi di Indonesia. Pemenuhan kebutuhan masyarakat terhadap majalah lebih menjangkau target pembaca yang segmented. Pada zaman modern, memang media cetak seperti majalah dapat mengarah kepada fungsi mendidik, menghibur dan mempengaruhi khalayak agar melakukan kegiatan tertentu. Ini kemudian memberikan tanda bahwa majalah punya makna yang luas dan menyeluruh segala aspek kehidupan masyarakat. Kemudian, tidak lama setelah itu kualitas media cetak di Indonesia semakin membaik, dari kualitas layout sampai pada isinya. Hal ini kemudian dikarenakan meningkatnya kualitas sumber daya manusia pengelolanya, serta 
banyaknya media cetak yang kemudian dikelola dengan manajemen profesional (Nur, 2019).

Daya tahan bisnis media cetak sebagai salah satu strategi kebijakan yang dapat dilakukan dengan mengakomodir selera dan kebutuhan pembaca serta terus melakukan inovasi dengan tetap meningkatkan kualitas berita yang dikemas secara komprehensif, objektif dan proposional sehingga tetap akurat (Hasni dkk,2019)

Jurnalistik krisis penangan Covid ini tidak hanya berupa teks yang muncul pada media, tetapi juga berupa gambar. Gambar muncul berupa video, foto dan ilustrasi. Media cetak dalam hal ini majalah memiliki elemen utama yaitu sampul majalah yang menjadi pintu utama dalam menyikapi pemberitaan yang ditampilkan.sampul majalah memiliki elemen foto dan ilustrasi.

Ilustrasi pada media publikasi telah menjadi bentuk penyampaian pesan lewat bertutur secara visual yang lebih kuat dibandingkan tulisan. Ilustrasi dapat membangun persepsi bagi yang melihatnya. Ilustrasi pada sampul muka sebagai pemberi identitas sekaligus menarik perhatian tidak terlepas dari peran sinergi antara penulis dan seniman dalam menghasilkan karya yang sanggup menyampaian pesan dalam bahasa visual (Adi, 2014).

Sampul majalah merupakan bagian penting dari etalase sebuah media cetak, dan setiap redaksional media mempunyai ciri khas dan karakternya sendiri dalam menentukan gaya sampul majalahnya secara konsep maupun teknik. Karakter yang berbeda menentukan pandangan majalah tersebut dalam menentukan visi dan misinya kepada target pembacanya. Dalam faktanya sampul majalah tidak hanya menyampaikan isi yang ada di dalamnya, tapi juga memaparkan perspektif dari majalah tersebut (Kurniawan,2016)

Desain sampul majalah bukan hanya sebuah proses artistik. Dalam kompetisi pasar yang fanatik, setiap publikasi harus membangun sebuah brand, menampilkan dan mewakili citra dari penerbitan tersebut dan sampulnya mewujudkan karakter serta menunjukkan jati diri atau ideologi dari majalah tersebut. Yang pertama dan utama, karena sebuah penerbitan majalah juga memiliki jaringan yang saling terkait antar bagian yang sangat penting antara penerbit, agen penjualan, dan pembaca (White, 2003: 185).

Sampul majalah merupakan sebuah media komunikasi visual yang menyampaikan pesan dari komunikator (penerbit) ke komunikan (pembacanya) selain bersifat informatif juga mempunyai fungsi promosi dan pemasaran yang bersifat komersial. Fungsi komunikasi tersebut bisa diidentifikasi sebagai berikut: (1) Dikenali dari bahasan/isu utamanya, menjadi ciri khas dari majalah tersebut, (2) Ketertarikan emosional, menjadi daya tarik dari tampilan muka sampul majalahnya, (3) Punya magnet untuk membangkitkan rasa keingintahuan pembaca, menarik perhatian audiens untuk membaca, dan memutuskan membeli, (4) Merangsang intelektualitas pemikiran pembaca, menjanjikan suatu manfaat apabila membeli majalah tersebut, (5) Efisien, cepat, dan mudah untuk dipahami, mengenalkan apa saja menu artikel yang 
ditawarkan, (6) Logis, masuk akal sebagai investasi wawasan pengetahuan bagi pembacanya.

Majalah Tempo sebagai media yang memfokuskan pada berita politik, dalam menampilkan etalasenya sering menggunakan simbol-simbol dalam ilustrasi sampulnya. Bentuk bahasa visual yang sering digunakan dalam sampul Tempo antara lain: (1) Satire, yaitu bentuk-bentuk gambar dalam ilustrasi yang berkesan mengejek atau menyindir secara halus atas realita (perilaku) yang sebenarnya melalui lakon, gestur, dan mimik yang dibentuk. Sesuai dengan definisinya, tokoh-tokoh yang tampil dalam sampul majalah dihadirkan dalam lakon yang kadang lucu, ada kesan bersandiwara, tidak kompak, saling menyalahkan, sembunyi, tampil naif, haus kekuasaan, dan jagoan. Lewat tampilan visual tersebut pesan yang ingin disampaikan adalah menyindir secara halus tanpa menyakiti. (2) Personifikasi, yaitu perumpamaan dari sifat atau sikap seseorang atau sebuah lembaga/institusi menampilkan wujud abstrak ke dalam wujud mahluk yang disimbolkan memiliki sifat-sifat mahluk hidup, contoh kasus cicak versus buaya antara POLRI yang disimbolkan buaya dan KPK yang disimbolkan sebagai cicak. (3) Ironi, gambar ilustrasi yang menampilkan bentuk visual dengan maksud menampilkan kenyataan yang bertolak belakang dengan keadaan yang sebenarnya, pesan ini bukan bermaksud menyindir tetapi lebih kepada menggugah hati dan pikiran. (4) Metafora, gambar ilustrasi yang menunjukkan dua hal yang memiliki kualitas yang sama dan membuat gambarannya semakin kuat. (5) Parodi, menggambarkan para tokoh dalam ilustrasi sampul majalah seolah-olah sedang memainkan peran lain atau meniruniru sosok lain yang menimbulkan kesan jenaka atau lucu. (6) Deskriptif, gambar ilustrasi yang menggambarkan apa adanya si obyek, sesuai dengan pesan yang ingin disampaikan, si obyek tetap menjadi dirinya sendiri (Nurhajati, dkk, 2012: 268-279).

Makna pada sampul majalah akan dikaji dengan menggunakan teori semiotika khususnya untuk sampul majalah yang menjadi ilustrasi jurnalistik. Semiotika merupakan ilmu yang membahas tentang tanda. Terbentuk dari sistem tanda yang terdiri dari penanda dan petanda. Bahasa adalah bentuk yang paling mencolok dari produksi tanda. Eco, menjelaskan istilah semiotika secara etimologis berasal dari kata Yunani semeion, berarti " tanda". Tanda didefinisikan sebagai sesuatu yang terbangun sebelumnya, dapat mewakili sesuatu yang lain. Dan secara terminologis, semiotika dapat didefinisikan sebagai ilmu yang mempelajari sederetan luas obyek-obyek, peristiwa, seluruh kebudayaan sebagai tanda (Sobur, 2009:12).

Sosok presiden Jokowi telah berkali-kali menjadi objek yang ditampilkan oleh sampul majalah Tempo sebagai berita utama dalam mengangkat isu kebijakan pemerintahannya. Termasuk dalam penangangan wabah pandemi Covid-19 di Indonesia. Sejak bermulanya virus ini di bulan Februari hingga Juni, terdapat empat kali edisi majalah Tempo memunculkan sosok Jokowi sebagai objek utama ilustrasi sampul depan terkait dengan pandemi Covid-19. 
Tampilan ilustrasi sosok Jokowi berupa satire, parodi dan metafora memiliki makna yang mendalam dalam merepresentasikan kebijakannya dalam penanganan pandemi Covid-19.

Berdasarkan latar belakang yang telah dijelaskan, penelitian ini bertujuan ingin mengkaji makna pada sampul majalah Tempo dalam edisi yang menampilan sosok Presiden Joko Widodo dalam menangani tahapan krisis pandemi Covid19 di Indonesia.

\section{METODE PENELITIAN}

Metode penelitian menggunakan pendekatan kualitatif. Menurut Denzin dan Lincon penelitian kualitatif membiarkan sebuah makna muncul dari partisipan-partisipan itu sendiri. Penelitian ini sifatnya lebih fleksibel sehingga dapat disesuaikan dengan latar yang ada ( Mulyadi dkk,2019:49).

Jenis Penelitian menggunakan jenis penelitian deskritif dan juga menggunakan studi semiotika Pierce. Semiotika sebuah ilmu yang mengkaji tanda-tanda yang ada di dalam suatu obyek. Pada penelitian ini obyek yang dikaji adalah sampul majalah Tempo yang menampilkan tokoh Presiden RI Joko Widodo dalam penanganan virus Covid-19.

Jenis data yang digunakan adalah jenis data primer. Data yang dimaksud adalah data yang didapatkan dari analisa 4 sampul majalah Tempo yang memunculkan tokoh presiden RI Joko Widodo. Sehingga peneliti melakukan analisis pada empat sampul majalah Tempo edisi 9-15 Maret 2020, 16-22 Maret 2020, 6-17 April 2020 dan 1-7 Juni 2020
Analisis menggunakan pendekatan studi semiotika Pierce. Analisis yang menekankan pada tanda sebagai ikon, indeks dan simbol. Berdasarkan objeknya, Pierce membagi tanda atas ikon, indeks, dan simbol (Sobur, 2009: 41-42). Ikon adalah tanda yang hubungan antara penanda atau petanda bersifat bersamaan bentuk alamiah. Ikon adalah hubungan antara tanda dan objek atau acuan yang bersifat kemiripan; misalnya, potret dan peta. Indeks adalah tanda yang menunjukan adanya hubungan alamiah antara tanda dan petanda yang bersifat kausal atau hubungan sebab akibat. Tanda dapat pula mengacu ke denotatum melalui konvensi. Tanda dapat pula mengacu kepada konvensional yang biasa disebut simbol. Simbol adalah tanda yang menunjukan hubungan alamiah antaran penanda dan petandanya. Hubungan diantaranya bersifat arbitrer atau semena, hubungan bedasarkan konvensi atau perjanjian masyarakat. Dengan mengunakan analisis semotika Pierce penulis akan menggali makna tanda ikon, indeks dan simbol kemudian menginterpretasikan keempat sampul majalah Tempo yang menampilkan sosok Presiden RI Joko Widodo dalam menangani pandemi Covid19.

\section{HASIL DAN PEMBAHASAN}

Pada hasil dan pembahasan penelitian ini. Analisa dilakukan pada ilustrasi sampul beserta teks yang muncul yang menampilkan Presiden Republik Indonesia, Joko Widodo dalam menghadapi pandemi Covid -19.Keempat sampul majalah Tempo yang dipilih berdasarkan tahapan Crisis and Emergency Risk Communication 
(CERC) menurut Reynolds dan Seger (dalam Utomo,2020:303-304)

Pertama pada tahapan awal krisis yang dimunculkan majalah Tempo edisi 9-15 Maret 2020. Diawal krisis, komunikasi krisis sudah siap dengan situasi yang berubah dengan cepat. Artinya, pemahaman akan skala krisis yang sudah datang akan memberikan pemahaman kepada publik posisi kita sudah ada di mana dalam situasi krisis. Berita- berita di media juga puny peran yang serupa dengan meletakkan kejadian awal ini dalam konteks yang relevan, tidak membesarbesarkan dan tidak meremehkan.

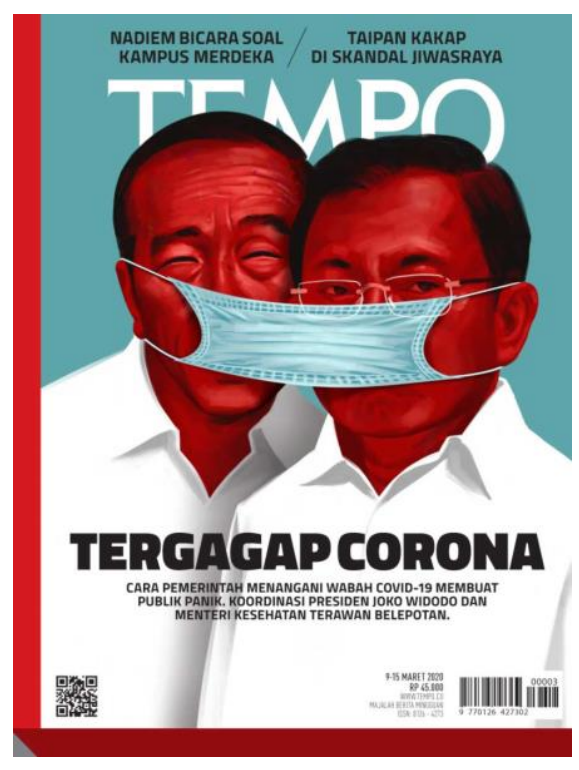

Sumber Majalah Tempo,2020

Gambar 1 Sampul Majalah Tempo Edisi 9-15 Maret 2020

Pada sampul tersebut objek gambar visual dan teks yang muncul adalah ilustrasi satire ikon Presiden Republik Indonesia bersama dengan Menteri Kesehatan Dr.Terawan berdampingan menggunakan satu masker medis. Sedangkan objek berupa teks dengan judul "TERGAGAP CORONA" dan sub Judul "Cara Pemerintah Menangani Wabah Covid-19 Membuat Publik
Panik. Koordinasi Presiden Joko Widodo dan Menteri Kesehatan Terawan Belepotan”.

Makna indeks memperlihatkan presiden Jokowi dan menteri Terawan dalam menghadapi wabah Covid-19 di Indonesia. Ekspresi wajah kedua tokoh tersebut terlihat berbeda satu sama lain. Wajah presiden Jokowi terlihat bahagia, meskipun tertutup masker, terlihat mata Jokowi yang menyipit dan kerutan wajah yang menandakan wajah bahagia.

Menurut Hadnagy dalam The Art of Human Hacking yang mengatakan bahwa ekspresi bahagia terlihat dari mimik yang dipancarkan wajah, mulai dari alis yang tertarik kebawah membuat mata yang menyipit, pipi yang tertarik ke atas dan mulut terbuka dan melebar ke sisi kanan dan kiri atau pun bibir yang tersenyum (Ramlam, 2019). Sedangkan berbeda dengan menteri Terawan yang menggunakan kacamata terlihat matanya yang sinis dan merasakan ketidaknyamanan berada di sebelah Jokowi.

Terlihat warna merah pada kulit kedua tokoh tersebut. Merah merupakan makna dari semangat dan kemarahan. Makna ini pun berbeda pada presiden Jokowi dan Mentri Terawan. Merah pada kulit Jokowi memaknai semangat dalam memerangi wabah Covid-19 sedangkan Terawan makna yang terbentuk ada merah sebagai bentuk kemarahan atau kekesalan.

Masker medis yang dipergunakan bersama kedua tokoh tersebut menjadi simbol dalam menghadapi virus Covid-19 yang penularannya dapat dicegah menggunakan masker. Masker yang mereka pergunakan berwarna hijau dan jenis 
masker medis yang digunakan bagi pasien positif covid dan tenaga medis. Selain masker yang digunakan bersama sebagai makna simbol kerjasama pemerintah dalam menghadapi virus Covid-19. Simbol lain yang terlihat adalah kemeja yang berwarna putih. Kemeja tersebut menjadi simbol kabinet Jokowi. Putih yang melambangkan keikhlasan dalam bekerja, semangat baru dan menjujung persatuan dan kesatuan.

Selain makna gambar pada sampul terdapat teks dengan font besar dan kapital sebagai penegasan judul "TERGAGAP CORONA". Arti tergagap merupakan perkataaan yang muncul saat kita berbicara dengan tersendat-sendat dan tertahan-tahan. Dengan sub judul "Cara Pemerintah Menangani Wabah Covid-19 Membuat Publik Panik.Koordinasi Presiden Joko Widodo dan Menteri Kesehatan Terawan Belepotan”. Teks ini memperlihatkan bahwa pemerintah belum menguasai komunikasi publik dalam menghadapi awal pandemi Covid 19. Sehingga informasi yang diberikan membuat masyarakat panik. Masyarakat panik karena perbedaan informasi yang berbeda-beda antara pejabat publik yang membuat kebingungan di masyarakat. Kata tergagap dan belepotan menjadi simbol komunikasi publik pemerintah yang masih berantakan dalam menyampaikan informasi Covid-19 ke masyarakat.

Interpretasi makna berdasarkan ikon,indeks dan simbol sampul halaman edisi 9-15 Maret adalah keterbukaan pemerintah mendeteksi dan menangani penyebaran virus corona dipertanyakan. Ekspresi yang berbeda antara kedua tokoh karena sebelum kasus pertama diumumkan, istana sesungguhnya sudah gusar terhadap cara Kementerian Kesehatan yang cenderung meremehkan cepatnya penyebaran virus yang bisa mematikan penderitanya ini. Menteri Terawan bahkan sempat menyarankan masyarakat berdoa agar tidak terkena Covid-19. Dia bahkan sempat meminta orang beramai-ramai melakukan salat istigasah agar Indonesia bebas Corona.Pernyataan Gaya komunikasi Terawan ini yang membuat masyarakat panik dan bentuk komunikasi publik pemerintah kepada masyarakat sangat terlihat tidak siap dan belum satu suara dalam menghadapi penyebaran virus ini.

Kedua, sampul majalah Tempo edisi 16-22 Maret 2020. Pada edisi ini krisis masuk pada tahapan maintenance, saat krisis sedang berlangsung dan membahas berbagai macam strategi yang akan dilakukan oleh pemerintah.

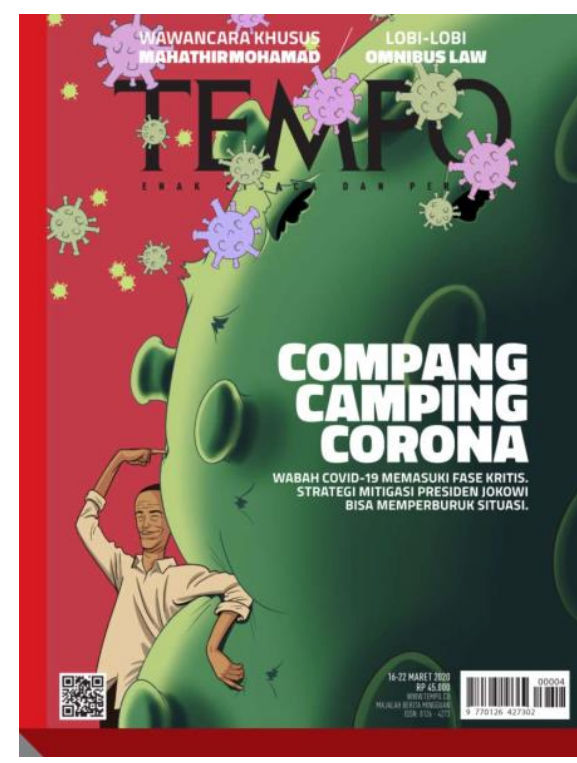

Sumber Majalah Tempo,2020

Gambar 2 Sampul Majalah Tempo Edisi 16-22 Maret 2020 
Objek ikon gambar dan teks pada sampul tersebut adalah Presiden Joko Widodo bersandar pada virus Covid-19 berukuran besar dengan judul "COMPANG CAMPING CORONA" dan sub judul" Wabah Covid-19 Memasuki Fase Kritis. Strategi Mitigasi Presiden Jokowi Bisa Memperburuk Situasi”.

Makna visual berupa indeks ilustrasi menyerupai bentuk mikro virus Covid-19 yang besar dan mengeluarkan banyak virus-virus kecil Covid-19 yang lebih banyak lagi. Makna ilustrasi menggambarkan virus yang semakin menyebar luas di wilayah Indonesia dengan semakin bertambahnya pasien positif Corona. Ilustrasi virus yang semakin besar seperti sebuah balon yang akan meletus. Tekstur virus tersebut terlihat seperti lapisan balon yang lentur saat disenderkan dan ditunjuk oleh Jokowi. Balon virus tersebut juga sudah mulai terlihat banyak kebocoran yang memiliki makna virus- virus mulai berkembang menyebar semakin banyak.

Terdapat warna yang berbeda - beda pada virus Covid-19 yaitu ungu, hijau dan pink. Berbeda dengan warna induk virus yaitu hijau. Hal ini memaknai bahwa virus telah mengalami mutasi yang menyebabkan perubahan gejala dan dampak yang dialami oleh pasien Covid-19

Jokowi kembali ditampilkan dengan menggunakan kembali kemeja putih. Kemeja tersebut sebagai simbol kabinet kerja Jokowi. Warna putih memiliki filosofi netral dan bersih. Sedangkan baju kemeja merupakan simbol kebaruan dan kerja keras. Ekspresi wajah yang ditampilkan Jokowi tampak bahagia, tidak ada kekhawatiran dan terlihat santai dengan semakin bertambahnya pasien positif Covid-19.

Pada makna teks dengan judul berhuruf kapital "COMPANG CAMPING CORONA” arti compang camping adalah koyak-koyak dengan buruk dan lusuh. Sehingga judul tersebut bermakna penanganan virus corona di Indonesia terlihat buruk dan tidak ditangani dengan baik.Hal ini ditegaskan dengan sub judul "Wabah Covid19 Memasuki Fase Kritis. Strategi Mitigasi Presiden Jokowi Bisa Memperburuk Situasi”.

Makna kata mitigasi dalam mitigasi bencana adalah serangkaian upaya untuk mengurangi resiko bencana, baik melalui pembangunan fisik maupun penyadaran dan peningkatan kemampuan menghadapi ancaman bencana. Pengertian tersebut berdasarkan Pasal 1 ayat 6 PP No 21 Tahun 2008 Tentang Penyelenggaraan Penanggulangan Bencana. Serangkaian upaya dalam kebijakan pemerintahan Jokowi selama pandemi ini berdasarkan teks tersebut dapat memperburuk penyebaran virus dan dampakdampak yang terjadi di masyarakat.

Interpretasi sampul halaman ini merupakan sikap pemerintah dalam hal ini Presiden Jokowi dalam menangani virus corona terus menuai kritik. Kekisruhan dalam pengadaan alat pendeteksi corona yang dimonopoli oleh Kementrian Kesehatan, hingga Presiden Jokowi menolak penyebaran corona disebut sebagai sebuah krisis.Meskipun setelah WHO menyatakan status pandemi Covid-19 dan 11 Maret pemerintah akhirnya menetapkan wabah corona sebagai bencana nasional. 
Pada masa ini Presiden Jokowi membentuk Gugus Tugas Percepatan Penanganan Covid-19 sayangnya kebijakan ini tidak dibarengi pemaparan strategi yang komprehensif dan transparan untuk membangun kepercayaan dan optimisme warga.Kepada pers, Presiden Jokowi justru mengakui bahwa pemerintah tidak menyampaikan semua data kepada masyarakat agar tidak terjadi kepanikan. Ini jelas kebijakan yang sungguh keliru.Sensor informasi justru membuat masyarakat bertanya-tanya tentang skala wabah ini.

Ketiga, Sampul majalah Tempo pada edisi 617 April 2020. Masih pada tahapan maintenance, pemerintah terus melakukan strategi dalam menetapkan kebijakan.

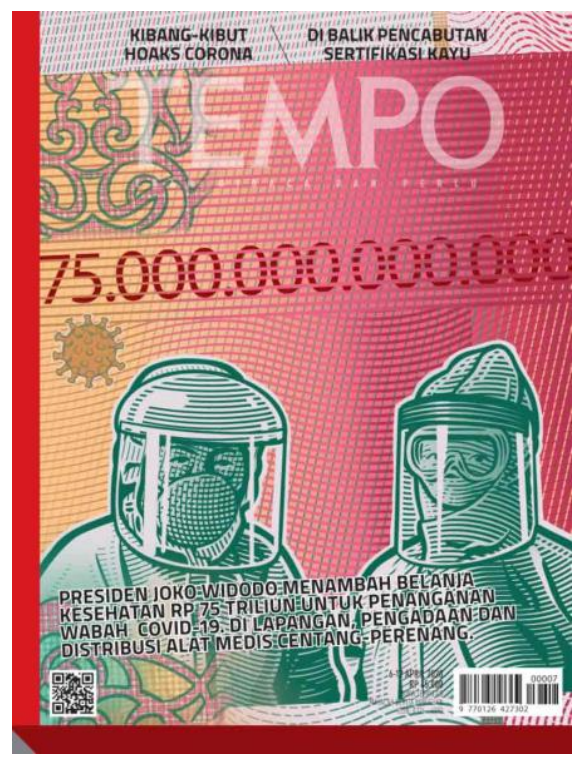

Sumber Majalah Tempo,2020

Gambar 3 Sampul Majalah Te mpo Edisi 6-17 April 2020

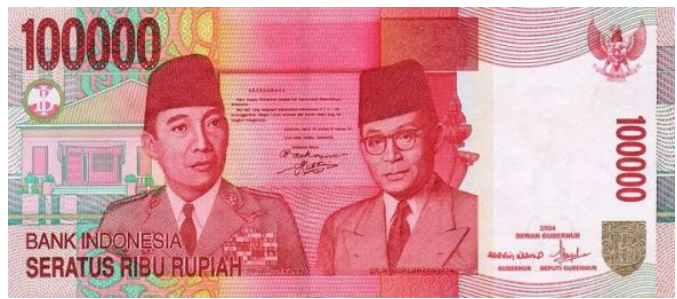

Sumber Bank Indonesia

Gambar 4 Tampilan Uang Kertas 100.000 Rupiah
Ikon gambar ilustrasi pada sampul halaman depan ini adalah Presiden Jokowi dan Menteri Keuangan Sri Mulyani menggunakan alat pelindung diri (APD) menyerupai tokoh Soekarno dan Hatta pada lembaran uang 100.000 rupiah. Terlihat kemiripan lembaran uang kertas tersebut dengan sampul yang ditampilkan edisi Tempo kali ini. Warna merah muda dan kuning,salur uang kertas dan motif batik pun terlihat jelas dengan logo ilustrasi virus Corona yang menggantikan logo Bank Indonesia.

Teks yang ditampilkan berjudul nominal “75.000.000.000.000" dan sub teks" Presiden Joko Widodo Menambah Belanja Kesehatan Rp.75 Triliun untuk penanganan wabah Covid-19. Di lapangan, pengadaan dan distribusi alat medis centang -perenang”

Pada ilustrasi ini sebagi indeks meskipun presiden Jokowi mengenakan APD, bisa terlihat jelas muka sosok Jokowi dari tatapan mata dan guratan wajah yang menyerupai presiden RI tersebut. Sedangkan pasangan disebelahnya tidak tampak jelas sebenarnya dalam menampilkan seorang tokoh. Jika dimiripkan sesuai dengan lembaran uang 100.000, pasangan Jokowi adalah wakil presiden Maaruf Amin. Tetapi pada tampak muka dibalik balutan APD, ilustrasi tersebut tidak sesuai dengan tokoh wakil presiden tersebut.

Berdasarkan analisis isi artikel terkait dengan pencairan dana 75 triliun oleh menteri Keuangan Sri Mulyani, bisa dipastikan tokoh disebalah preseiden Jokowi adalah menteri keuangan wanita 
tersebut. Terlihat dari raut wajah yang ditampilkan adalah sosok seorang wanita.

Nominal 75 triliun merupakan jumlah dana yang digulirkan pemerintah untuk biaya penanganan pandemi Covid-19 khususnya untuk pengadaaan alat kesehatan termasuk APD sehingga di ilustrasi tersebut Jokowi dan Sri Mulyani menggunakan APD lengkap. Uang lembaran 100.000 ribu dipilih karena menjadi nominal uang tertinggi di mata uang Indonesia. Simbol 100ribu memaknai banyaknya dana yang digulirkan pemerintah untuk penanganan wabah Covid-19.

Objek teks yang dimaknai adalah sub judul “ Presiden Joko Widodo Menambah Belanja Kesehatan Rp.75 Triliun untuk penanganan wabah Covid-19. Di lapangan, pengadaan dan distribusi alat medis centang -perenang”. Pada teks ini memiliki makna bahwa presiden Jokowi memberikan tambahan Rp.75 Triliun untuk penanganan wabah Covid-19. Meskipun sebelumnya sudah ada dana yang dialokasikan untuk pandemi ini, berjalannya virus ini menyebar di Indonesia. Presiden kembali menambahkan anggaran khusus pada krisis ini.

Kemudian pada kalimat lanjutan " $d i$ lapangan, pengadaan dan distribusi alat medis centang- perenang". Terdapat penegasan kata baku "centang - perenang" dalam pelaksanan penggunaan dana tersebut saat sudah sampai di lapangan.

Arti kata Centang-perenang adalah tidak beraturan letaknya (malang melintang dan sebagainya); porak-parik; berantakan. Kata ini menjadi indeks bahwa pelaksanaan penggunaan dana yang besar ini masih berantakan dalam pelaksanaannya di lapangan.

Interpretasi makna pada sampul majalah pada edisi ini adalah Menteri keuangan Sri Mulyani Indrawati memaparkan detail rencana tambahan belanja tersebut. Dana senilai Rp. 75 triliun dialokasikan diantaranya khusus pengadaaan alat tes corona, alat pelindung diri tenaga medis, dan sarana-sarana kesehatanlainnya. Jumlah nominal yang tidak sedikit ini Seluruh pengadaan itu harus dicermati karena waktu belanja yang mendesak dan jumlah produk yang terbatas biasanya mengundang terjadinya moral hazard. Situasi kritis memang kerap menggoda para penanggung jawab anggaran dan pelaku bisnis megambil jalan pintas.

Keempat, analisi pada edisi 1-7 Juni, Tempo menampilkan tahapan saat krisis ini sudah sampai ditahap resolution. Tahap ini pada dasarnya merujuk pada proses komunikasi krisis yang mesti dilakukan jika sudah diketahui atau setidaknya bisa diprediksi kapan krisis yang ada akan berakhir. Media punya peran yang serupa, mengidentifikasikan dampak yang mungkin ditimbulkan oleh krisis yang ada dan apa yang akan terjadi sesudah krisis berakhir termasuk proses recovery yang dibutuhkan (Utomo,2010:304) 


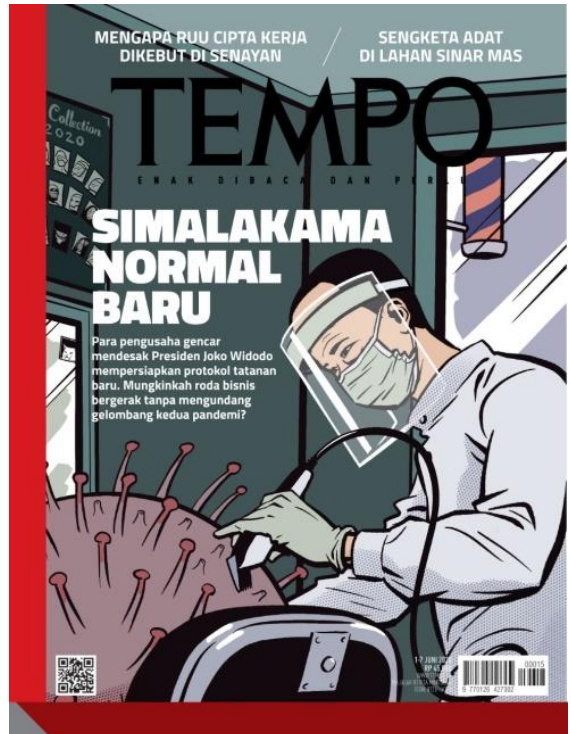

Sumber Majalah Tempo,2020

Gambar 5 Sampul Majalah Tempo Edisi 1-7 Juni 2020

Pada sampul keempat ini objek visual dan teks adalah ikon ilustrasi presiden Jokowi berprofesi sebagai tukang cukur rambut yang sedang mencukur rambut virus covid -19. Edisi ini berjudul " SIMALAKAMA NORMAL BARU” dengan sub judul "Para Pengusaha Gencar Mendesak Presiden Joko Widodo Mempersiapkan Protokol Tatanan Baru. Mungkinkah Roda Bisnis Bergerak Tanpa Mengundang Gelombang Kedua?"

Dalam ilustrasi personafikasi ini presiden Jokowi sebagai tukang cukur rambut dapat dilihat dari luar ruangan yang terdapat ikon barber's pole yaitu Tiang tukang cukur atau berupa lampu adalah jenis tanda yang digunakan oleh tukang cukur untuk menandakan tempat atau toko pangkas rambut mereka. Menurut tradisi berasal dari Abad Pertengahan, tongkat dengan helix garis-garis berwarna biru, merah dan putih. Sedangkan di dalam ruangan ditampilkan poster “collection 2020". Meskipun poster tersebut hanya terlihat sebagian, tetapi terlihat beberapa foto.
Pada pangkas rambut poster berupa contoh gayagaya rambut yang sedang trend. Sedangkan ditampilan poster tersebut adalah berbagi macam foto orang -orang dengan berbagai macam penggunaan masker penutup muka, topeng dan APD yang menjadi simbol selama wabah Covid19.

Pak Jokowi ditampilan sebagai tukang cukur rambut dengan pelanggannya. Simbol menghadapi normal baru terlihat pada perlengkapan yang yang digunakan presiden jokowi berupa face shield atau pelindung wajah, sarung tangan dan masker. Jokowi juga sedang menggunakakan alat cukur rambut atau hair clipper.Balutan simbol yang dimunculkan sekali lagi oleh majalah Tempo adalah kemeja putih yang menjadi simbol kerja kabinet Jokowi.

Sedangkan pada kursi cukur pelanggan bukanlah sosok manusia yang dihadirkan melainkan ilustrasi virus Covid -19. Presiden Jokowi dalam ilustrasi ini dimaknai akan hidup berdampingan dengan Covid-19 dengan menetapkan protokol kesehatan. Dengan ekspresi muka yang tampak serius Presiden Joko Widodo mencukur rambut virus Covid-19 dengan hair clipper, ilustrasi rambut adalah bagian dari virus itu sendiri yang disebut dengan Spike Glycoprotein $S$ atau duri protein. Berfungsi sebagai peleburan antara membran virus dan sel inang (manusia). Jokowi pada ilustrasi tersebut telah memangkas beberapa duri proten virus yang memiliki makna, telah mengurangi setidaknya penyebaran virus Covid -19. 
Edisi ini berjudul " SIMALAKAMA NORMAL $B A R U$ " makna teks ini menjadi ikon pada kata simalakama. Berdasarkan KKBI simalakama dari kata dasar malakam ,buah yang baik dimakan maupun tidak menyebabkan bencana (hanya untuk perumpamaan): menghadapi keadaan yang serba salah (apa pun yang dilakukan akan mendatangkan kesulitan). Makna kata ini jelas memposisikan kebijakan Jokowi dalam menerapkan new normal atau normal baru dalam kehidupan beraktifitas selama wabah Covid-19 masih berlangsung.

Dengan sub judul "Para Pengusaha Gencar Mendesak Presiden Joko Widodo Mempersiapkan Protokol Tatanan Baru. Mungkinkah Roda Bisnis Bergerak Tanpa Mengundang Gelombang Kedua?" Penekanan kata simalakama ditegaskan pada sub judul di atas. Posisi Jokowi dalam menerapkan protokol tatanan baru ini dalam situasi yang serba salah. Jika tidak segera diberlangsungkan, kehidupan ekonomi negara akan memburuk. Desakan datang terutama dari kalangan pengusaha yang hampir lebih 3 bulan di masa pandemi ini mengalami kesulitan dalam altivitas usaha mereka yang terpaksa terhambat bahkan terhenti. Di satu sisi belum adanya vaksi bahkan obat yang mujarab untuk menghentikan virus ini belum ditemukan, sedangkan pasien positif Corona setiap hari nya terus bertambah di Indonesia. Sehingga membuat dileme besar jika perekonomian normal berjalan akan mengakibatkan semakin meningkatnya dalam tahap lanjutan dari wabah Covid-19 ini.
Interpretasi sampul majalah edisi tatanan baru ini bermakan bahwa lobi-lobi pengusaha ikut mendorong pemerintah memberlakukan normal baru di tengah pandemi corona. Tanpa indikator jelas, pemerintah menetapkan puluhan daerah untuk menetapkan tatanan baru. Presiden jokowi mulai menganjurkan masyarakat hidup berdampingan dengan covid-19 dan menetapkan new normal.

Berdasarkan salah satu artikel di majalah tersebut. pernyataan Badan Kesehatan Dunia (WHO) bahwa virus corona tak akan hilang, Jokowi meminta masyarakat tetap produktif sambil menerapkan protokol kesehatan secara ketat." Seperti yang saya sampaikan sebelumnya, berdamai dengan Covid-19. Sekali lagi, yang penting masyarakat produktif, aman, dan nyaman," kata presiden melalui keterangan resmi dari istana merdeka, Jumat 15 Mei.

Sampul majalah pada edisi ini memberikan makna keseriusan sosok presiden Jokowi dalam menetapkan protokol tatanan baru meskipun dalam posisi situasi yang belum terbebas dari wabah Covid-19. Di harapkan masyarakat dapat hidup berdampingan dengan virus yang sampai saat ini masih menjadi pandemi secara global.

Sampul majalah Tempo dengan ilustrasinya menjadi sebuah ciri khas daya tarik secara emosional calon pembaca, membangkitkan rasa keingintahuan pembaca, menarik perhatian audiens untuk membaca, dan memutuskan membeli. Ilustrasi sampul sosok Jokowi dalam analisis semiotika merangsang intelektualitas 
pemikiran pembaca. Terhadap persepsi pandangan dari ideologi majalah Tempo.

\section{SIMPULAN}

Sampul majalah tempo merupakan jurnalistik dalam bentuk ilustrasi gambar dan teks yang memiliki makna. Wabah Covid-19 yang menjadi pandemi secara global menjadi news value yang tinggi oleh media. Termasuk majalah Tempo yang menjadi kan berita ini headline dan sampul majalahnya.Pemaknaan pada sampul majalah Tempo di masa ini terbagi menjadi tiga tahap dalam menampilkan sosok presiden Joko Widodo. Tahapan awal krisis, maintance dan tahapan resolusi krisis di masa Pandemi Covid-19. Sosok Jokowi berdasarkan analisis semiotik Pierce digambarkan sebagai pemimpin yang santai pada tahap awal krisis hingga maintance di masa pandemi Covid -19. Ilustrasi makna dalam bentuk satire dan metafora melalui ilustrasi ekspresi sosok Jokowi yang ditampilkan. Sedangkan keseriusan sosok Jokowi ditampilkan pada masa resolusi dalam bentuk personifikasi, saat Indonesia masuk tatanan kehidupan normal bersama Covid-19. Pemaknaan yang dilakukan oleh majalah Tempo melalui sampul majalah terhadap sosok Jokowi sering kali dilakukan. Pada masa Pandemi Covid-19 ini sosok Jokowi ditampilkan sebagai bentuk kritik media terhadap segala kebijakan yang dikeluarkan pada masa pemerintahan presiden Jokowi.

\section{DAFTAR PUSTAKA}

\section{Buku:}

Mulyadi,Seto.Basuki, Heru. Prabowo, Hendro. (2019).Metode Penelitian Kualitatif dan Mixed Method. Depok: PT.Raja Grafindo Persada.
Nurhajati Lestari, Dkk. (2012). Rupa Kata I. Kumpulan Tulisan Seni Rupa. Jakarta: FSR IKJ Press.

Sobur, Alex.(2009).Analisis Teks, Suatu Pengantar Untuk Analisis Wacana, Analisis Semiotika dan Analisis Framing. Bandung : PT.Remaja Rosdakarya.

Utomo, W. P.(2020). Jurnalisme Krisis Dan Krisis Jurnalisme Di Era COVID-19.In.Mas'udi,W. Winanti,P.(Ed.), Tata Kelola Penangana COVID-19 Di Indonesia:Kajian Awal (pp.300320).Yogyakarta:Gadjah Mada University Press.

White, Jan V. 2003. Editing by Design for Designers, Art Directors and Editors. third edition. USA: Allworth Press.

\section{Jurnal:}

Adi, D. (2014). Memaknai bahasa visual pada ilustrasi bergambar Soeharto di sampul muka majalah Tempo. Humaniora, 5(2), 612-623.

Hasni, N., Cangara, H., \& Fatimah, J. M. (2019). Daya Tahan Bisnis Media Cetak Ditengah Maraknya Penggunaan Media Online Di Kota Makassar (Skh Fajar Dan Skh Tribun Timur). Medialog: Jurnal Ilmu Komunikasi, 2(1), 41-53.

Kurniawan, E. (2016). Kajian Makna Di Balik Sampul Majalah Tempo (Studi Kasus "Sampul Rekening Gendut Perwira Polisi", Edisi Senin, 28 Juni 2010). Jurnal Dimensi DKV Seni Rupa Dan Desain, 1(1), 47-56.

Nur, S. N. (2019). Majalah Pecinan Terkini Sebagai Media Komunikasi Komunitas Tionghoa Di Kota Makassar. Medialog: Jurnal Ilmu Komunikasi, 2(2), 21-33.

Ramlan, W., \& Supratman, L. P. (2019). Analisis Semiotika Charles Sanders Peirce Pada Sampul Majalah Tempo Edisi Satu Perkara Seribu Drama. eProceedings of Management, 6(2).

Website:

https://majalah.tempo.co/gallery 